\title{
Developing Two New Tundish Plasters and Comparing with the Magnesia Plaster Used in Continuous Casting of Steel
}

\author{
M. Kalantar, B.M. Moshtaghioun, and A. Monshi
}

\author{
(Submitted August 30, 2008; in revised form March 16, 2009)
}

\begin{abstract}
In the continuous casting of steel, the porous structure of tundish plaster with high-MgO content is commonly used. Destruction of this type of plaster is the result of silicate phases with low melting points that are created when slag containing $\mathrm{SiO}_{2}$ and $\mathrm{CaO}$ penetrates into pores of plaster and reacts with periclase (MgO). In this study, two new plasters are developed and their performances in contact with slag are compared with the common plaster by using crucible test. In these new plasters, part of magnesia is replaced by chromite and olivine. Experimental work indicated that basicity gap between slag and plasters is reduced. Destructive reactions between penetrated slag and these new porous plasters are inhibited and phases with high melting points are formed on the surface of primary grains, leading to less dissolution of plasters in slag. This means that the life time of tundish plaster is increased. The reason is that chromite and olivine have less tendency to react with slag rich in $\mathrm{SiO}_{2}$ and probability of formation of destructive silicate phases such as monticellite and merwinite is reduced.
\end{abstract}

Keywords basicity gap, chromite, magnesia, olivine, plaster of tundish, salg resistance

\section{Introduction}

In the continuous casting of steel, a tundish is used as an intermediate vessel between a ladle and a mold to provide a reservoir of liquid metal, and to distribute the liquid steel to the mold. As such, tundish is a vessel in which a series of operations occur that require chemical, thermal, and physical control. The quality of the liquid product delivered from tundish to the mold thus depends highly on the degree of interaction of slag and possible gases with the refractory phases (Ref 1, 2).

Typically tundish linings are composed of three layers. The working lining or plaster is a high- $\mathrm{MgO}$ material and is exposed directly to the steel $(\operatorname{Ref} 1,3)$. There are a number of different types of tundish linings available in the market place today. These include, in roughly chronological order, 'bricked,' 'gunnable,' 'board,' 'sprayable,' and recently in situ formed 'dry' systems (Ref 4). In order to use the tundish as more than just a steel reservoir for feeding the caster, several different tundish flux formulations have been proposed to the steel as it passes through the tundish. The fluxing composition is both

M. Kalantar, Department of Materials Engineering, Yazd University, Yazd, Iran; and B.M. Moshtaghioun and A. Monshi, Department of Materials Engineering, Isfahan University of Technology (IUT), Isfahan 84156, Iran. Contact e-mail: mmoshtagh@ma.iut.ac.ir. insulating and basic and performs the following three vital functions as it covers the liquid metal in a tundish:

1. Thermal insulation of the liquid steel.

2. Provision of a barrier to reoxidation.

3. Assimilation of salg and inclusions, thereby, cleansing the steel $(\operatorname{Ref} 5,6)$.

The backup lining is generally made of high alumina refractory and is the thickest part of the tundish lining. This backup lining has a low reactivity with magnesia materials to form a surface working layer and have affinity for the safety lining. The third component of the tundish refractory system is a safety lining. This high insulating lining is installed over backup lining to provide thermal insulation and keep the steel shell temperature below its critical temperature range throughout the operating campaigns of a tundish (Ref 1,7$)$.

There are several major reasons why steelmakers use coating materials to line the tundish rather than running directly on the backup lining, such as: provide insulation to preserve heat in the molten steel, provide an inert barrier between the steel and backup lining, and act as a parting plane for easy deskulling ( $\operatorname{Ref} 7)$.

To reach these properties, refractory materials of working lining for tundish are improved wherein the principal component is magnesia. The void forming materials such as mainly paper fiber (pulp) and other materials like styrofoam beads made from expanded polystyrene beads, glass wool and slag wool are used. The drawbacks of using fillers to reduce the density and to provide insulation of the lining material are that the fillers reduce the strength and chemical durability of resulting lining and produce undesirable interconnected porosity. The working tundish lining refractory composition further includes a binder based on silicates or phosphates; a plasticizer which enhances adherence of the composition when applied to 
the backup lining; a bond stabilizer; a homogenizer; and in certain cases, a small amount of a wetting/foaming agent (Ref 8).

Reaction between the working liner material and tundish slag is of great concern especially in shops running long sequence casts. In practice, tundish slags vary widely in composition, not only from shop to shop, but also during a single sequence. It is not unusual to have both a very basic slag and also a very acidic slag. Thus, no one refractory composition will work best for all slag conditions likely to be encountered (Ref 7). The corrosion of refractories in molten slags depends strongly on the viscosity of slag and also the basicity gap between the refractories and the slags. In developing high corrosion resistance refractories, it has been emphasized that the basicity of the refractory composition must be brought close to the basicity of slag (Ref 9, 10). During the corrosion of refractories, the primary liquid slag penetrates into refractory by the capillary pressure action that results in more active interaction of phases and dissolution of the refractory in the slag. In this initial stage, the surface tension at the boundary surface of phases is the driving force of the process. Therefore, the specific surface of the refractory and the presence of micropores and other microdefects on the refractory surface are significant factors for this stage (Ref 11).

In this study for reducing the corrosion rate of working lining of tundish, the refractory compositions with two principal components of magnesia-chromite and magnesia-olivine are introduced. The aim of this study is investigation and comparison of the reactions involved and phases formed during penetration of slags into porous structure of the developed compositions with respect to the high- $\mathrm{MgO}$ materials.

\section{Materials and Methods}

The crucible tests were carried out using three different types of samples. One of them, M, was commonly used in the steel companies and was made from high-MgO materials. The others were new working linings which were introduced in this study. In one of them, O, half part of the magnesia (about $50 \%$ of aggregates) was replaced by olivine and in another, $\mathrm{C}$, half part of magnesia (about $50 \%$ of aggregates) was replaced by chromite. The chemical compositions of these working linings are shown in Table 1 . The crucibles were made, first by mixing the working lining material with $25 \mathrm{wt} . \%$ of water, then by casting the mixtures in $45 \times 45 \times 30 \mathrm{~mm}^{3}$ molds with $25 \times 25 \times 15 \mathrm{~mm}^{3}$ inner cavity. These crucibles were dried in an oven at $110{ }^{\circ} \mathrm{C}$ for $2 \mathrm{~h}$ and then were fired at the temperature of $500{ }^{\circ} \mathrm{C}$ for $3 \mathrm{~h}$. After curing, crucibles were preheated at $1200{ }^{\circ} \mathrm{C}$ for $2 \mathrm{~h}$ to have a heat treatment similar to that applied in industry. They were then filled with an industrial homogenized tundish slag. In the continuous casting of steel, the tundish slag has a variable chemical analysis in different sequences. In this study, for having slag with constant composition, the collected alloy steel slag of tundish during different sequences were ground and mixed with ball mill for $30 \mathrm{~min}$. The composition of this homogenized slag is given in Table 2. The oxides of $\mathrm{SiO}_{2}, \mathrm{CaO}, \mathrm{MgO}, \mathrm{MnO}$ and in some cases together with $\mathrm{Al}_{2} \mathrm{O}_{3}$ and $\mathrm{FeO}$ are main slag components that aggressively attack refractory materials in industrially important processes $(\operatorname{Ref} 12,13)$. The crucibles filled with slag powder were fired at $1600{ }^{\circ} \mathrm{C}$ for $2 \mathrm{~h}$ to provide almost the same slag-refractory condition of industry for reactions to occur.

X-ray powder diffraction patterns were recorded at room temperature by means of a Philips MPD-X'PERT. $\mathrm{Cu} k_{\alpha}$ radiation $(\lambda=1.542 \AA)$ composed of $\mathrm{Cu} k_{\alpha 1}$ and $\mathrm{Cu} k_{\alpha 2}$ radiation was employed in a Philips instrument.

For microstructural characterization, samples with an area of about $2 \mathrm{~cm}^{2}$ were polished. The polished samples were coated with a conductive gold layer to examine of the slag/refractory interface with a scanning electron microscope (Philips XL30 SERIES) equipped with energy dispersive spectroscopy (EDS). This elemental analysis has been converted to oxide basis by calculations, since the slag is composed of different oxides of the elements.

To convert elements to oxides, 100 atom (mole) of elements was taken as basis. From $x_{i}$ atom of metal ion $i$, the equivalent $y_{i}$ mole of related oxide was calculated. Then all of the oxide moles were added to the summation of $\sum_{i=1}^{n} y_{i}$ moles. The mole fraction of any oxide could be calculated as $100 \cdot\left(y_{i} / \sum_{i=1}^{n} y_{i}\right)$. The moles were then multiplied by molecular weight of each oxide to give the weight of that oxide, $z_{i}$, and the summation of $\sum_{i=1}^{n} z_{i}$. From this, weight percent of each oxide was calculated as $100 \cdot\left(z_{i} / \sum_{i=1}^{n} z_{i}\right)$. Since the EDS analysis is semiquantitative and evaluation of oxygen content is more erroneous than metal detection, this approach seems to be more reliable than any other procedure based on oxygen content. Table 3 shows the typical calculation for point $\mathrm{E}$ in Fig. 4. It must be noted that the values of weight percent for each oxide as $10.4,14.5,60.3$, and 14.8 are calculated equivalents with weight percent of that element as 8.04, $10.43,55.83$, and 15.60 , respectively. In practice, one decimal point is more realistic than two decimal points given by the instrument for elemental concentration and estimates of error in the analysis are taken, respectively, as $10.4 \pm 0.5 \%$, $14.5 \pm 0.5 \%, 60.3 \pm 0.5 \%$, and $14.8 \pm 0.5 \%$, which accounts for an uncertainty of about $1 \%$.

Table 2 The composition of homogenized slag powder

\begin{tabular}{lccccccc}
\hline \%SiO $_{2}$ & $\% \mathrm{CaO}$ & $\% \mathrm{MgO}$ & $\mathbf{\% A l}_{2} \mathrm{O}_{3}$ & $\% \mathrm{MnO}$ & $\% \mathrm{FeO}$ & $\% \mathrm{Fe}$ & $\% \mathrm{TiO}_{\mathbf{2}}$ \\
\hline 31.56 & 30.02 & 15.02 & 6.25 & 10.04 & 4.06 & 5.43 & 0.38 \\
\hline
\end{tabular}

Table 1 Chemical composition of three different plasters which has been used

\begin{tabular}{|c|c|c|c|c|c|c|c|}
\hline Sample & \%MgO & $\% \mathrm{SiO}_{2}$ & $\% \mathrm{CaO}$ & $\% \mathrm{Al}_{2} \mathrm{O}_{3}$ & $\% \mathrm{Cr}_{2} \mathrm{O}_{3}$ & $\% \mathrm{Fe}_{2} \mathrm{O}_{3}$ & \%L.O·I \\
\hline M & 83.52 & 5.26 & 3.81 & 0.92 & - & 0.59 & 2.76 \\
\hline $\mathrm{C}$ & 48.15 & 5.26 & 2.50 & 14.69 & 16.62 & 7.67 & 2.94 \\
\hline $\mathrm{O}$ & 60.28 & 17.40 & 4.25 & 4.13 & 1.50 & 4.92 & 2.99 \\
\hline
\end{tabular}


Table 3 The typical element to oxide conversion of EDS microanalysis for the point $E$ in Fig. 4

\begin{tabular}{|c|c|c|c|c|c|c|c|c|}
\hline Element & Wt.\% & $\begin{array}{c}\text { Atomic\% } \\
\text { or mole\% }\left(x_{i}\right)\end{array}$ & $\begin{array}{l}\text { Equivalent } \\
\text { oxide }\end{array}$ & $\begin{array}{c}\text { Number of } \\
\text { oxide moles, } \\
y_{i} \text { based on } x_{i} \\
\text { of the element }\end{array}$ & 100 . & $\begin{array}{l}\text { Mole\% } \% \\
\left(y_{i} / \sum_{i=1}^{n} y_{i}\right)\end{array}$ & $\begin{array}{c}\text { Weight of the } \\
\text { oxide }\left(z_{i}\right)\end{array}$ & $\begin{array}{c}\text { Wt.\% of oxide } \\
100 \cdot\left(z_{i} / \sum_{i=1}^{n} z_{i}\right)\end{array}$ \\
\hline $\mathrm{O}$ & 10.10 & 23.22 & & & & & & \\
\hline $\mathrm{Mg}$ & 8.04 & 12.89 & $\mathrm{MgO}$ & 12.89 & & 25.8 & 1032 & 10.4 \\
\hline $\mathrm{Al}$ & 10.43 & 14.17 & $\mathrm{Al}_{2} \mathrm{O}_{3}$ & 7.08 & & 14.2 & 1448.4 & 14.5 \\
\hline $\mathrm{Cr}$ & 55.83 & 39.46 & $\mathrm{Cr}_{2} \mathrm{O}_{3}$ & 19.73 & & 39.5 & 6004 & 60.3 \\
\hline $\mathrm{Fe}$ & 15.60 & 10.26 & $\mathrm{FeO}$ & 10.26 & & 20.5 & 1476 & 14.8 \\
\hline Total & 100 & 100 & & 49.96 & & 100 & 9960.4 & 100 \\
\hline
\end{tabular}

\section{Results and Discussion}

\subsection{SEM Observations and EDS Analyses of Slag/Refractory Interface}

Figure 1 shows the microstructure of sample $M$ near the outer surface of the crucible in a backscattered image of SEM instrument. The heavier elements look brighter and the lighter elements look darker in the backscattered image. Figure 2 shows the EDS microanalysis of points A and B shown in Fig. 1. Figure 2(a) gives the microanalysis of point A in Fig. 1, which is a $\mathrm{MgO}$ grain. Figure 2(b) shows the chemical composition high in $\mathrm{CaO}$ content and low $\mathrm{SiO}_{2}$ and $\mathrm{MgO}$ contents. It is near the slag composition and it confirms that point B in Fig. 1 is penetrated slag into pores of plaster, coming into contact with $\mathrm{MgO}$ grains. For further investigation, SEM backscattered observation and EDS analysis are carried out in an area of crucible which is nearest to slag. The results are shown in Fig. 3 and Table 4. These results are obtained similar to the previous one. The EDS microanalysis of point $\mathrm{A}^{\prime}$ in Fig. 3 is again a $\mathrm{MgO}$ grain which is destroyed by the attacking slag and involves $\mathrm{SiO}_{2}, \mathrm{CaO}$, and $\mathrm{MnO}$ to some extent beside $\mathrm{MgO}$. The presence of $\mathrm{MnO}$ illustrates the penetration of this oxide from the slag and tends to create a new phase with $\mathrm{MgO}$ on the $\mathrm{MgO}$ grains as seen in Fig. 3.

Figures 4 and 5 similarly illustrate the penetration of slag into pores of sample $\mathrm{C}$ in an area near the outer and inner surfaces of the crucible, respectively. The EDS microanalysis of sections that are shown in Fig. 4 and 5 are indicated in Table 5. The point $\mathrm{D}$ in Fig. 4 and also point $\mathrm{D}^{\prime}$ in Fig. 5 are basically a $\mathrm{MgO}$ grain. A new phase rich in $\mathrm{SiO}_{2}$ content has developed on its surface. $\mathrm{SiO}_{2}$ comes from penetrated slag and is richer in the area near the inner surface of crucible than in the area near the outer surface of the crucible. Points $\mathrm{E}$ and $\mathrm{E}^{\prime}$ are a chromite grain. The chromite grain composition is generally (Fe, $\mathrm{Mg}) \mathrm{O}(\mathrm{Cr}, \mathrm{Al}, \mathrm{Fe})_{2} \mathrm{O}_{3}$ or the spinel phase of $(\mathrm{Fe}, \mathrm{Mg})(\mathrm{Cr}, \mathrm{Al}$, $\mathrm{Fe})_{2} \mathrm{O}_{4}$. Points $\mathrm{F}$ and $\mathrm{F}^{\prime}$ are similar to slag composition. But the composition is higher in $\mathrm{MgO}$ content in the area near the inner surface of crucible that confirms $\mathrm{MgO}$ grains have been dissolved in the slag. This slag has not been able to increase its $(\mathrm{Cr}, \mathrm{Al}, \mathrm{Fe})_{2} \mathrm{O}_{3}$ content. The presence of, respectively, $1.2 \%$ and $3.3 \% \mathrm{Cr}_{2} \mathrm{O}_{3}$ content in points $\mathrm{F}$ and $\mathrm{F}^{\prime}$ illustrates the resistance of the spinel $(\mathrm{Mg}, \mathrm{Fe})(\mathrm{Cr}, \mathrm{Al}, \mathrm{Fe})_{2} \mathrm{O}_{4}$ phase of chromite to being dissolved in the slag.

SEM backscattered observation (Fig. 6 and 7) and EDS analysis (Table 6) were carried out also for sample $O$ in two mentioned regions. The microanalysis of points $\mathrm{G}$ and $\mathrm{G}^{\prime}$ illustrates the presence of olivine that was replaced to $50 \%$ of

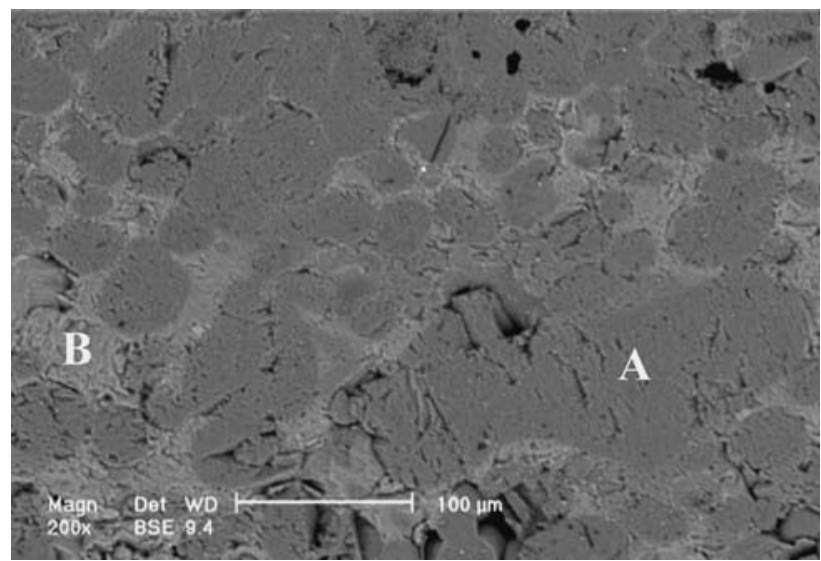

Fig. 1 SEM backscattered electron image of plaster $M$ near the outer surface of the crucible, after penetration of slag into pores

magnesia in this sample. Olivine is a natural mineral in the form of sand particles, essentially composed of about $90 \mathrm{wt} \%$ forsterite $\left(2 \mathrm{MgO} \cdot \mathrm{SiO}_{2}\right.$ or $\left.\mathrm{Mg}_{2} \mathrm{SiO}_{4}\right)$ and around $10 \mathrm{wt} . \%$ fayalite $\left(2 \mathrm{FeO} \cdot \mathrm{SiO}_{2}\right.$ or $\left.\mathrm{Fe}_{2} \mathrm{SiO}_{4}\right)$. These two silicates are in the form of solid solutions, because they are completely soluble and there is no limit of solid solubility. The case is similar to that of $\mathrm{MgO}$ and $\mathrm{FeO}$ that produce magnesiuferrite $(\mathrm{Mg}, \mathrm{Fe}) \mathrm{O}$ extending from $0 \%$ to $100 \% \mathrm{FeO}$. The points $\mathrm{H}$ and $\mathrm{H}^{\prime}$ indicate infiltrated slag. From EDS analysis of point $\mathrm{H}^{\prime}$ near the inner surface of crucible, it is clear that dissolution of $\mathrm{MgO}$ grains is low, because the $\mathrm{MgO}$ content did not change considerably compared with the area near the outer surface of crucible (point $\mathrm{H}$ ). This phenomenon confirms development of phases on $\mathrm{MgO}$ grains that protect them from slag attack and this is the reason why the $\mathrm{MgO}$ grains are not observed in Fig. 6 and 7.

The silica content of pure homogenized slag $(31.56 \%$ in Table 2$)$, the slag region in outer surface of crucible $(27.4 \%$ in point $\mathrm{H})$, and slag region in inner surface of crucible $(30.3 \%$ in point $\mathrm{H}^{\prime}$ ) are all essentially the same. Identical $\mathrm{SiO}_{2}$ content of slag in different conditions means that olivine, $2(\mathrm{Mg}$, $\mathrm{Fe}) \mathrm{O} \cdot \mathrm{SiO}_{2}$ is not dissolved in the slag.

\subsection{X-Ray Diffraction Analysis}

X-ray diffraction pattern of the uncorroded sample $\mathrm{M}$ (Fig. 8, lower XRD pattern) contains large amounts of $\mathrm{MgO}$ or periclase. Slag penetration causes large changes in the crystalline phases of the sample (Fig. 8, upper XRD pattern). The phases such as monticellite $\left(\mathrm{CaMgSiO}_{4}\right)$, merwinite 

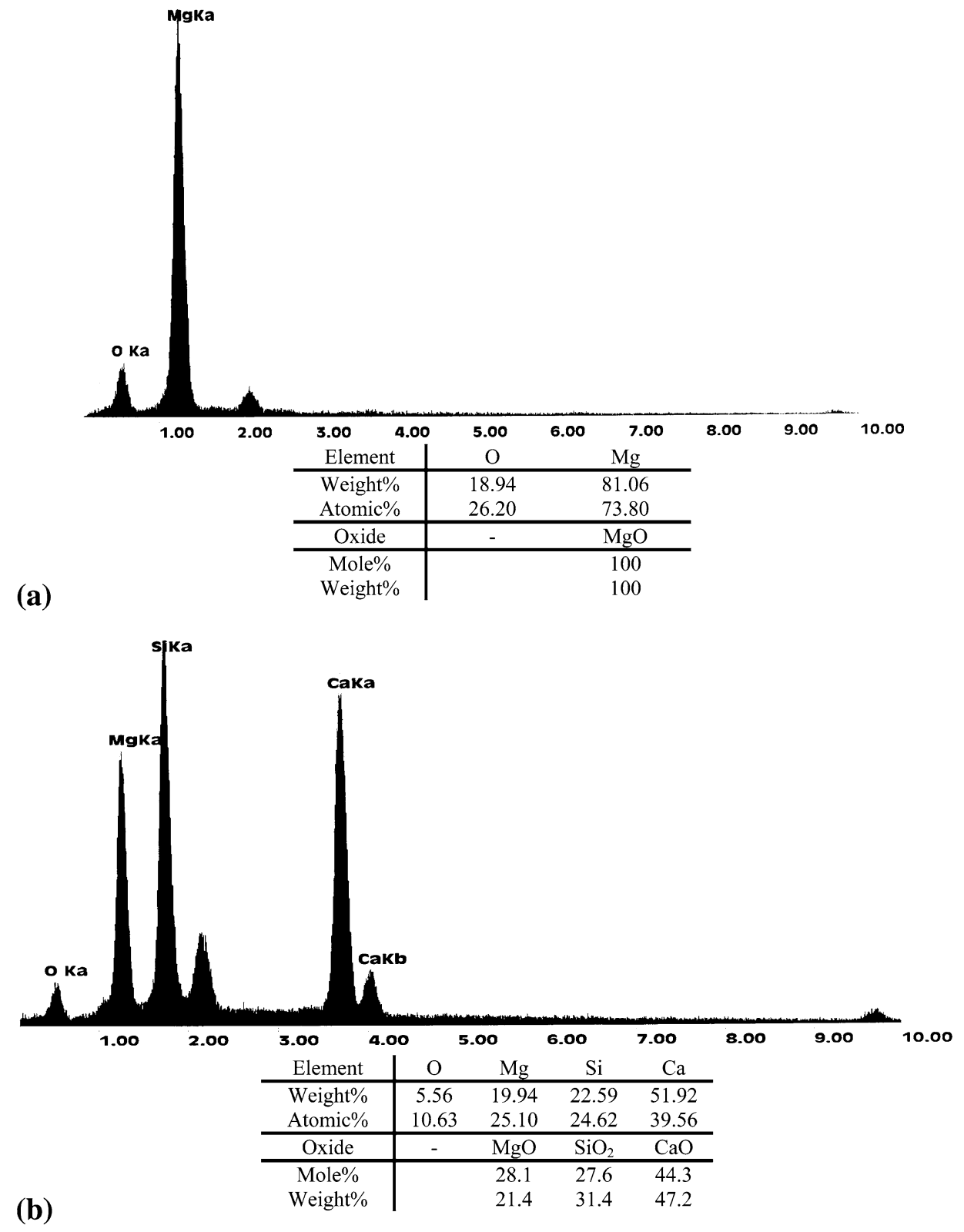

Fig. 2 EDS microanalysis of (a) point A and (b) point B in Fig. 1

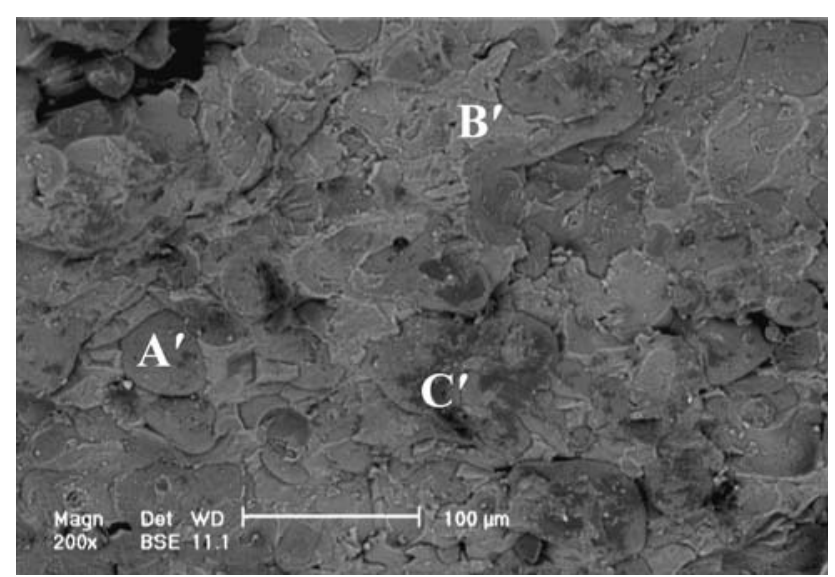

Fig. 3 SEM backscattered electron image of plaster $M$ near the inner surface of the crucible, after penetration of slag into pores
Table 4 Microanalysis results of points $A^{\prime}, B^{\prime}$, and $C^{\prime}$ in Fig. 3

\begin{tabular}{lccc}
\hline Oxide analysis & Point $\mathbf{A}^{\prime}$ & Point $\mathbf{B}^{\prime}$ & Point $\mathbf{C}^{\prime}$ \\
\hline $\mathrm{m} / \mathrm{o} \mathrm{(a)} \mathrm{MgO}$ & 79.7 & 32.6 & 85.8 \\
$\mathrm{w} / \mathrm{o}$ (b) $\mathrm{MgO}$ & 70.8 & 24.9 & 77.8 \\
$\mathrm{~m} / \mathrm{o} \mathrm{SiO} 2$ & 4.8 & 26.7 & 2.6 \\
$\mathrm{w} / \mathrm{o} \mathrm{SiO}$ & & 30.6 & 3.5 \\
$\mathrm{~m} / \mathrm{o} \mathrm{CaO}$ & 6.4 & 38.0 & - \\
w/o CaO & 4.7 & 40.8 & - \\
m/o $\mathrm{MnO}$ & 5.8 & 2.7 & 11.6 \\
w/o $\mathrm{MnO}$ & 10.8 & 3.7 & 18.7
\end{tabular}

(a) $\mathrm{m} / \mathrm{o}=$ mole $\%$
(b) $\mathrm{w} / \mathrm{o}=$ wt. $\%$ 


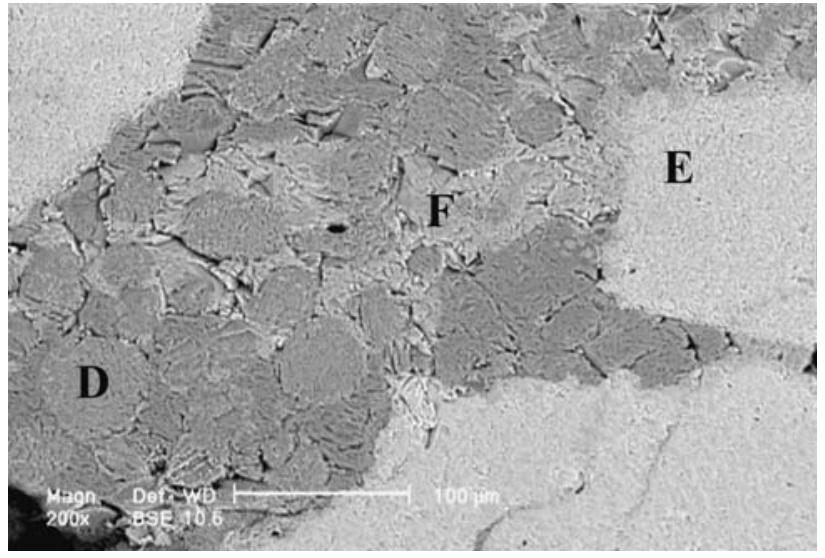

Fig. 4 SEM backscattered electron image of plaster $C$ near the outer surface of the crucible, after penetration of slag into pores

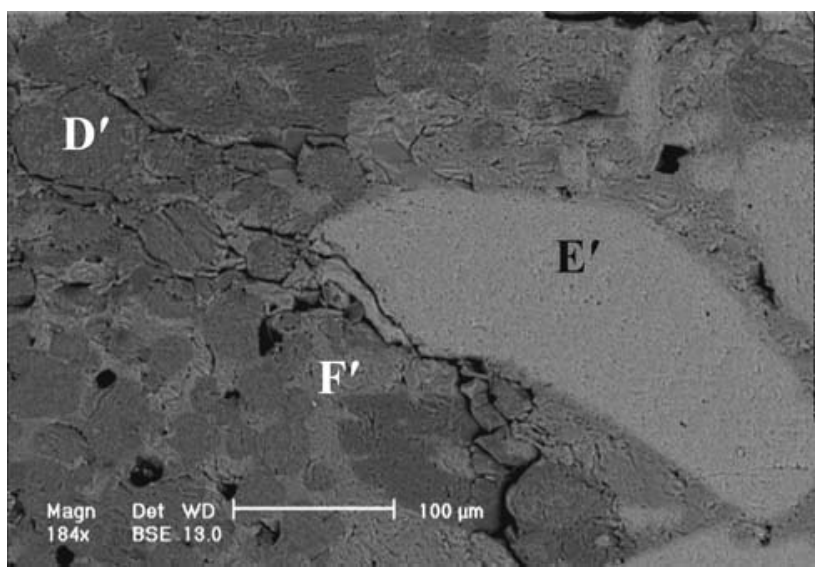

Fig. 5 SEM backscattered electron image of plaster $\mathrm{C}$ near the inner surface of the crucible, after penetration of slag into pores

Table 5 Microanalysis results of points of D, E, F (Fig. 4) and points $\mathbf{D}^{\prime}, \mathbf{E}^{\prime}, \mathbf{F}^{\prime}$ (Fig. 5)

\begin{tabular}{|c|c|c|c|c|c|c|}
\hline $\begin{array}{l}\text { Oxide } \\
\text { analysis }\end{array}$ & Point D & Point $\mathbf{D}^{\prime}$ & Point E & Point $\mathbf{E}^{\prime}$ & Point F & Point $\mathbf{F}^{\prime}$ \\
\hline $\mathrm{m} / \mathrm{o} \mathrm{MgO}$ & 69.1 & 48.4 & 25.8 & 31.5 & 27.6 & 54.4 \\
\hline w/o MgO & 60.0 & 38.8 & 10.4 & 12.2 & 20.6 & 43.7 \\
\hline $\mathrm{m} / \mathrm{o} \mathrm{SiO}_{2}$ & 28.3 & 40.0 & - & - & 25.9 & 24.0 \\
\hline w/o $\mathrm{SiO}_{2}$ & 36.8 & 48.2 & - & - & 29.0 & 29.0 \\
\hline $\mathrm{m} / \mathrm{o} \mathrm{CaO}$ & 2.6 & 11.6 & - & - & 42.7 & 18.1 \\
\hline w/o $\mathrm{CaO}$ & 3.2 & 13.0 & - & - & 44.6 & 20.5 \\
\hline $\mathrm{m} / \mathrm{o} \quad \mathrm{Al}_{2} \mathrm{O}_{3}$ & - & - & 14.2 & 15.9 & - & - \\
\hline w/o $\mathrm{Al}_{2} \mathrm{O}_{3}$ & - & - & 14.5 & 15.7 & - & - \\
\hline $\mathrm{m} / \mathrm{o} \mathrm{Cr}_{2} \mathrm{O}_{3}$ & - & - & 39.5 & 45.4 & 0.4 & 1.1 \\
\hline w/o $\mathrm{Cr}_{2} \mathrm{O}_{3}$ & - & - & 60.3 & 67.1 & 1.2 & 1.3 \\
\hline $\mathrm{m} / \mathrm{o} \mathrm{FeO}$ & - & - & 20.5 & 7.2 & 3.4 & 2.4 \\
\hline w/o FeO & - & - & 14.8 & 5.0 & 4.6 & 3.5 \\
\hline
\end{tabular}

$\left(\mathrm{Ca}_{3} \mathrm{Mg}\left(\mathrm{SiO}_{4}\right)_{2}\right)$, and tephroite $\left(\mathrm{Mn}_{2} \mathrm{SiO}_{4}\right)$ have been developed. It was shown in Fig. 3 and Table 4 that when slag was approached to be in contact with $\mathrm{MgO}$ grains, it reacted on the surface of $\mathrm{MgO}$ grains and the above phases developed. Since

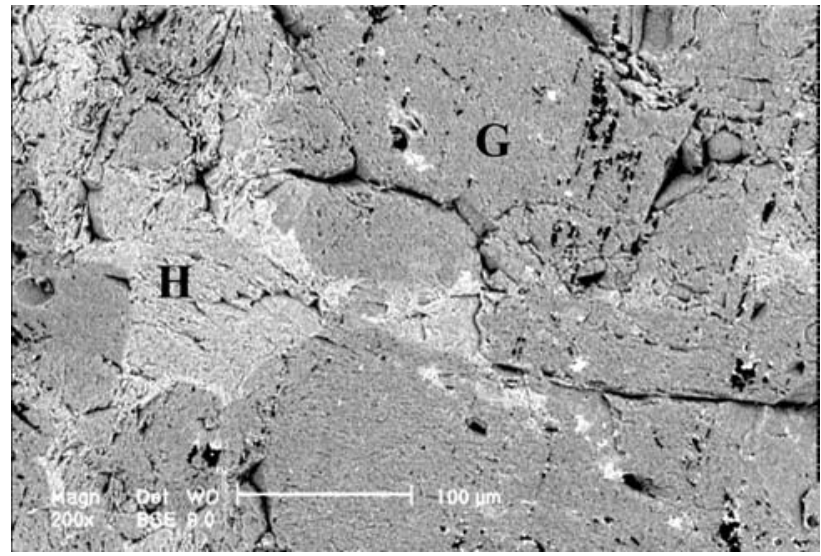

Fig. 6 SEM backscattered electron image of $O$ plaster near the outer surface of the crucible, after penetration of slag into pores

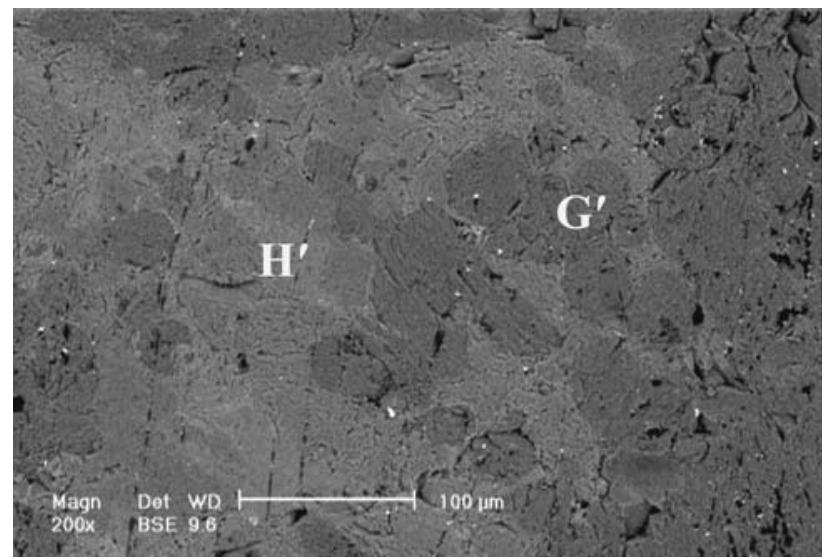

Fig. 7 SEM backscattered electron image of $O$ plaster near the inner surface of the crucible after penetration of slag into pores

Table 6 Microanalysis results of points of G, H (Fig. 6) and points $\mathbf{G}^{\prime}, \mathbf{H}^{\prime}$ (Fig. 7)

\begin{tabular}{lcccc}
\hline Oxide analysis & Point $\mathbf{G}$ & Point $\mathbf{G}^{\prime}$ & Point $\mathbf{H}$ & Point $\mathbf{H}^{\prime}$ \\
\hline m/o $\mathrm{MgO}$ & 71.3 & 64.2 & 22.4 & 35.5 \\
w/o $\mathrm{MgO}$ & 62.6 & 53.9 & 16.4 & 27.2 \\
m/o $\mathrm{SiO}$ & 23.7 & 26.6 & 24.9 & 26.4 \\
w/o $\mathrm{SiO}$ & 31.3 & 33.5 & 27.4 & 30.3 \\
m/o $\mathrm{CaO}$ & 5.0 & 4.3 & 45.9 & 32.6 \\
w/o $\mathrm{CaO}$ & 6.1 & 5.1 & 47.2 & 34.9 \\
m/o FeO & - & 4.9 & 6.8 & 5.5 \\
w/o FeO & - & 7.5 & 9.0 & 7.6 \\
\hline
\end{tabular}

the temperature of steel melt in tundish is around $1600{ }^{\circ} \mathrm{C}$ or higher, these phases with melting points of monticellite $\left(1498{ }^{\circ} \mathrm{C}\right)$, merwinite $\left(1575^{\circ} \mathrm{C}\right)$, and tephroite $\left(1345^{\circ} \mathrm{C}\right)$ are all melted and result in the continuation of $\mathrm{MgO}$ dissolution in slag (Ref 14, 15).

X-ray diffraction pattern of uncorroded sample C (Fig. 9, lower XRD pattern) gives evidence to the presence of large amounts of $\mathrm{MgO}$ and chromite $\left((\mathrm{Mg}, \mathrm{Fe})(\mathrm{Cr}, \mathrm{Al}, \mathrm{Fe})_{2} \mathrm{O}_{4}\right)$. After 


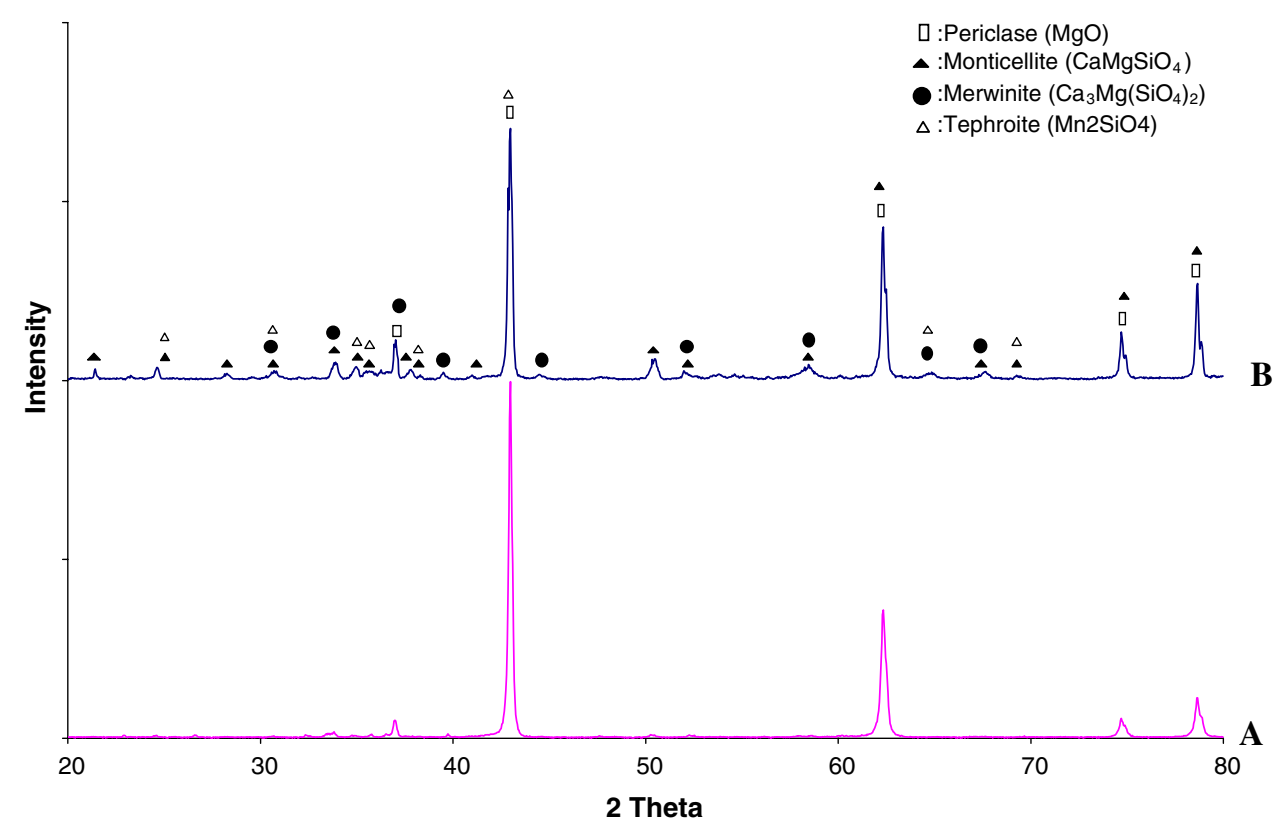

Fig. 8 XRD results of plaster M both before (a) and after (b) reaction with slag

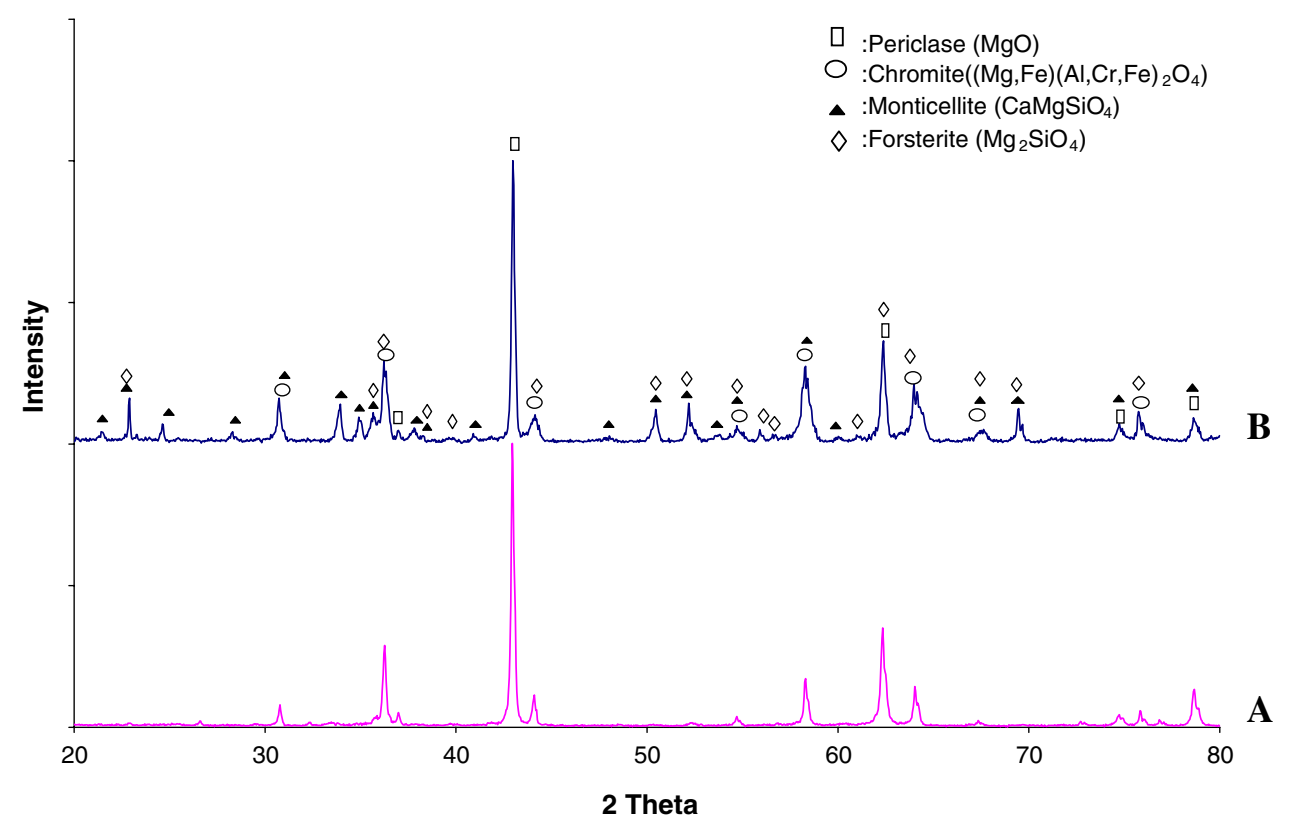

Fig. 9 XRD results of plaster $\mathrm{C}$ both before (a) and after (b) reaction with slag

corrosion, those two phases are still present. Moreover, XRD exhibits monticellite $\left(\mathrm{CaMgSiO}_{4}\right)$ and forsterite $\left(\mathrm{Mg}_{2} \mathrm{SiO}_{4}\right)$ (Fig. 9, upper XRD pattern). Formation of forsterite with melting point of $1890{ }^{\circ} \mathrm{C}$ is confirmed in EDS analysis of point $\mathrm{D}$ and $\mathrm{D}^{\prime}$. This phase at the temperature of steel melt in tundish $\left(\approx 1600{ }^{\circ} \mathrm{C}\right)$ is solid and is developed on the surface of $\mathrm{MgO}$ grains. Therefore, the corrosion of sample is decreased, and destructive phases such as merwinite and tephroite do not form. It seems that the amount of monticellite which is formed in this sample in comparison with sample $\mathrm{M}$ is decreased. The reason for this phenomenon is solid layer of forsterite that is formed on the surface of $\mathrm{MgO}$ grains. Chromite phase has high resistance in contact with slag.

Picrochromite or $\mathrm{MgCr}_{2} \mathrm{O}_{4}$ spinel is one of the most important spinels of chromite. So, in this sample after being in contact with slag, the $\mathrm{SiO}_{2}-\mathrm{MgO}-\mathrm{MgO} \cdot \mathrm{Cr}_{2} \mathrm{O}_{3}$ triangle that is some part of $\mathrm{SiO}_{2}-\mathrm{MgO}-\mathrm{Cr}_{2} \mathrm{O}_{3}$ system is of interest, as shown in Fig. 10. According to this triangle that is identified in $\mathrm{SiO}_{2}$ $\mathrm{MgO}-\mathrm{Cr}_{2} \mathrm{O}_{3}$ diagram (Ref 16), forsterite is one of the phases which is stable in vicinity of $\mathrm{MgO}$ and is created in presence of 


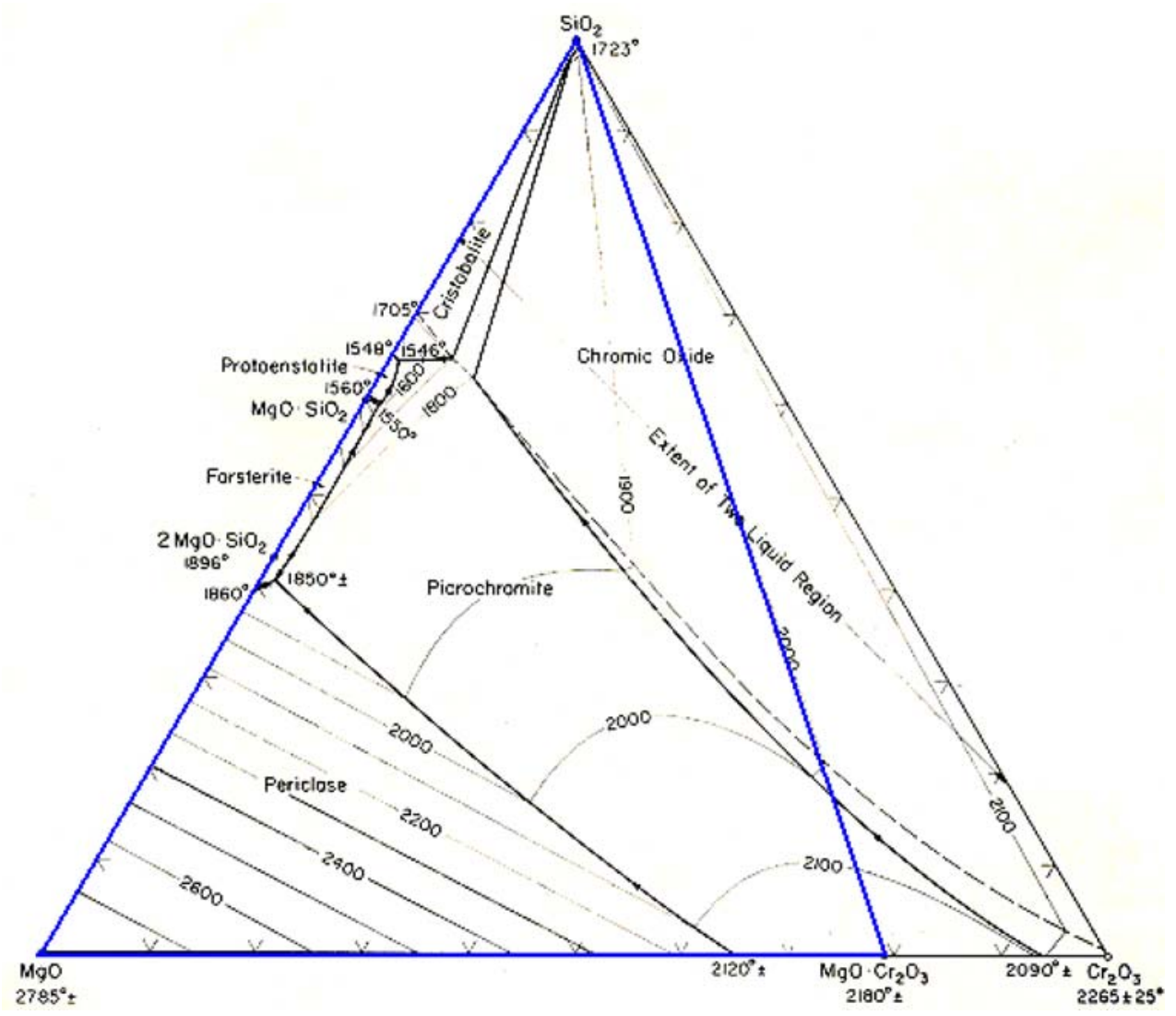

Fig. 10 Phase diagram of the $\mathrm{SiO}_{2}-\mathrm{MgO}-\mathrm{Cr}_{2} \mathrm{O}_{3}$ system (Ref 16)

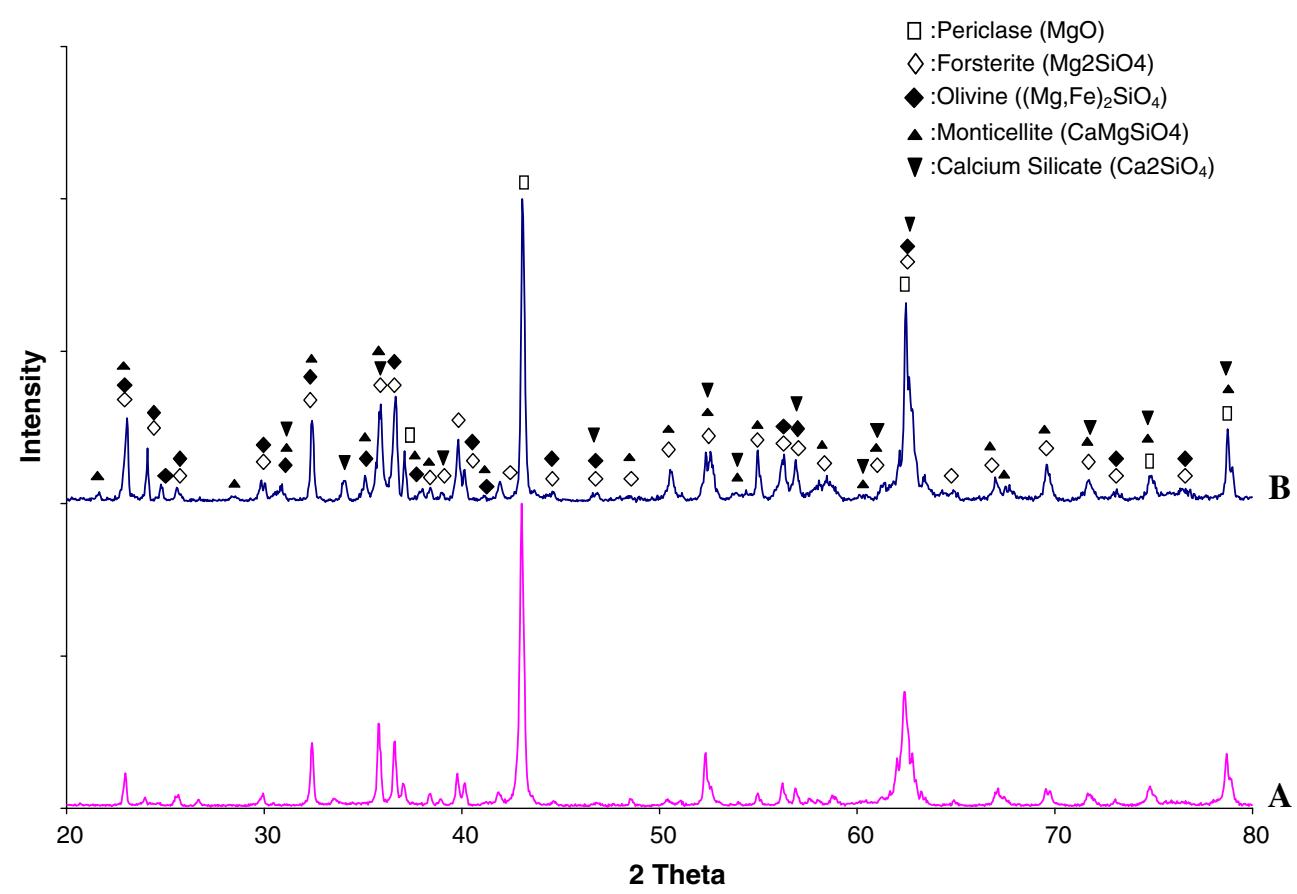

Fig. 11 XRD results of plaster $\mathrm{O}$ both before (a) and after (b) reaction with slag

$\mathrm{SiO}_{2}$ of slag on the surface of $\mathrm{MgO}$ grains. According to phase diagram of Fig. 10, when we have two grains of magnesia, $\mathrm{MgO}$, and picrochromite, $\mathrm{MgCr}_{2} \mathrm{O}_{4}$, and a liquid rich in $\mathrm{SiO}_{2}$ (slag) between them, forsterite can be formed in very low concentration of picrochromite. This means that liquid (slag melt) containing $\mathrm{SiO}_{2}$ reacts with the surface of $\mathrm{MgO}$ grains to 


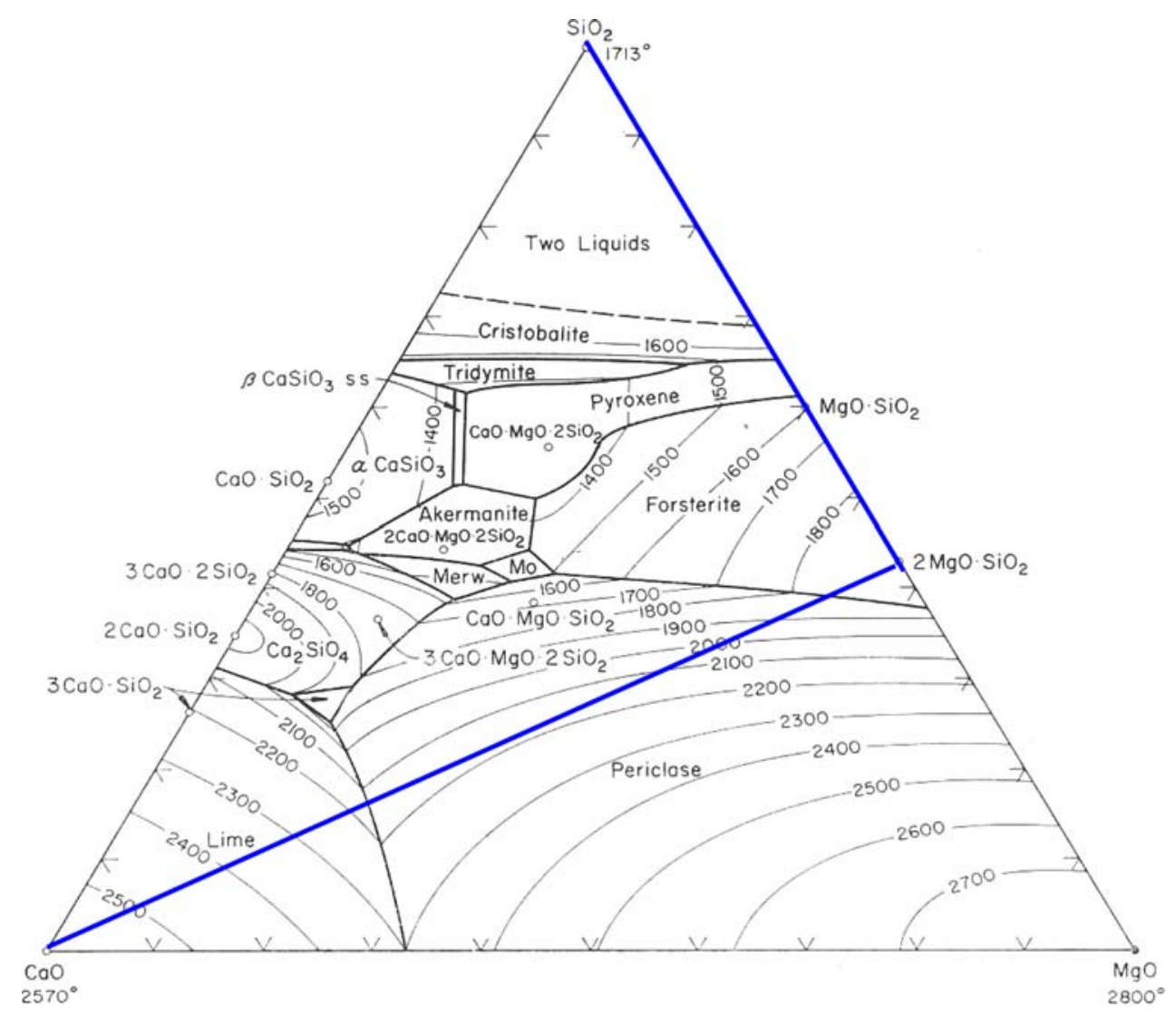

Fig. 12 Phase diagram of the $\mathrm{SiO}_{2}-\mathrm{MgO}-\mathrm{CaO}$ system (Ref 16)

develop forsterite, $2 \mathrm{MgO} \cdot \mathrm{SiO}_{2}$, in presence of picrochromite. This hypothesis that is supported by XRD phase analysis is interesting from this point of view that chromite mineral, which is natural spinel, not only resists corrosive attack of silica rich slag by itself, but also provides a protective passive layer of forsterite on the surface of $\mathrm{MgO}$ grains and inhibits their dissolution in slag melt.

Before corrosion, $\mathrm{x}$-ray diffraction of sample $\mathrm{O}$ evidences, besides $\mathrm{MgO}$, the presence of olivine (Fig. 11, lower XRD pattern). Interaction with slag leads to changes in the $\mathrm{X}$-ray diffraction pattern. $\mathrm{MgO}$ and olivine $\left((\mathrm{Mg}, \mathrm{Fe})_{2} \mathrm{SiO}_{4}\right)$ remain and olivine provides potential site for nucleation and development of phases such as forsterite $\left(\mathrm{Mg}_{2} \mathrm{SiO}_{4}\right)$ and calcium silicate $\left(\mathrm{Ca}_{2} \mathrm{SiO}_{4}\right)$ (Fig. 11, upper XRD pattern). The melting points of forsterite and calcium silicate are 1890 and $\approx 2000{ }^{\circ} \mathrm{C}$, respectively. So, these phases are solid in tundish at temperature of steelmaking $\left(\approx 1600{ }^{\circ} \mathrm{C}\right)$ and surround the different primary grains of the plaster. Since these phases have high resistance in contact with slag, development of these phases especially on the surface of $\mathrm{MgO}$ grains is suitable for protection of $\mathrm{MgO}$ grains from slag attack. But the presence of some monticellite in this sample is also confirmed.

In the $\mathrm{CaO}-\mathrm{MgO}-\mathrm{SiO}_{2}$ system (Ref 16), with a line drawn between forsterite and $\mathrm{CaO}$, all of the reactions that can be created between $\mathrm{CaO}$ of slag and forsterite which is the main phase in the olivine, are located on this line, as shown in Fig. 12. From this figure, it can be understood that the phases such as monticellite and merwinite do not form. So, it can be concluded that $\mathrm{CaO}$ of slag does not have any destructive effect on forsterite of plaster. The possible reaction between silica content of slag and forsterite is Enstatite, $\mathrm{MgO} \cdot \mathrm{SiO}_{2}$, with a melting point of not much less than $1600{ }^{\circ} \mathrm{C}$.

In the samples $\mathrm{C}$ and $\mathrm{O}$, merwinite phase that is formed by reaction between slag and $\mathrm{MgO}$ grains is not detected. In addition, the samples $\mathrm{C}$ and $\mathrm{O}$ especially sample $\mathrm{O}$ have better performance in contact with slag, because of the formation of the phases on the surface of primary grains of plaster. This phenomenon is due to the fact that the refractory composition by adding chromite or olivine is brought closer to the basicity of slag and the basicity gap between the slag and new plasters is reduced (Ref 9, 10). So, replacing part of $\mathrm{MgO}$ by olivine or chromite is a promising industrial application for producer of tundish plaster. This means that the life time of tundish working lining is increased.

\section{Conclusion}

When slag penetrates into pores of common plaster with high$\mathrm{MgO}$ content, the phases such as monticellite and merwinite develop around $\mathrm{MgO}$ grains and provide continuous dissolution of $\mathrm{MgO}$ grains during steel-making process. Replacing part of the magnesia of plaster by chromite or olivine is promising for decreasing the hot corrosion. This is because the basicity gap between introduced plasters and tundish slag decreases and also causes the formation of phases with high melting point on the surface of primary grains of $\mathrm{MgO}$ and decreases the dissolution of plaster in the slag. Therefore, the life time of these plasters is increased to higher sequences. 


\section{Open Access}

This article is distributed under the terms of the Creative Commons Attribution Noncommercial License which permits any noncommercial use, distribution, and reproduction in any medium, provided the original author(s) and source are credited.

\section{References}

1. J.P. Birat, C. Chow, and T. Emi, The Making, Shaping and Treating of Steel, 11th ed., The AISI Steel Foundation, 20B, Casting volume, 2003

2. A. McLean, The Turbulent Tundish-Contaminator or Refiner? Proceedings Steelmaking Conference on Iron and Steel Society, Vol. 71, 1998, p 3-23

3. Committee on Technology, Refractory Materials for Steelmaking, International Iron and Steel Institute, Brussels, 1985

4. G. Connor, Chemically Bonded Tundish Lining System and Associated Near Tundish Refractories, Foseco Steel International report, 2002

5. B.J. Barker, Basic Tundish Flux Composition for Steelmaking. US Patent 6179895 B1, 30 Jan 2001

6. L.J. Heaslip and J.D. Dorricott, Basic Tundish Covering Compound. US Patent 5366 535, 22 Nov 1994

7. J.W. Stendera, The Basics of Tundish Slurry Spray, Refract. Appl. News, 2002, 6, p 26-31
8. J.A. Cheng and W.A. Matinez, Lightweight Tundish Refractory Composition. US Patent 5073 525, 17 Dec 1991

9. T. Hirata, T. Mrimoto, S. Ohta, and N. Uchida, Improvement of the Corrosion Resistance of Alumina-Chromia Ceramic Materials in Molten Slag, J. Eur. Ceram. Soc., 2003, 23, p 2089-2096

10. K. Sugita, Refractories for Iron and Steelmaking, Chijin Shokan Co., Ltd, Tokyo, 1995, p 147-153

11. E. Medvedovski, Liquid-Phase Sintering from the High-Temperature Corrosion Process Standpoint, Mater. Chem. Phys., 2001, 67, p $32-36$

12. J.A. Bonar, C.R. Kennedy, and R.B. Swaroop, Coal-Ash Slag Attack and Corrosion of Refractories, Am. Ceram. Soc. Bull., 1980, 59(4), p 473-478

13. C.R. Kennedy, Compatibility of Water-Cooled Chromia-Containing Refractories with a High Iron Oxide Acidic Coal-Ash Slag at $1575^{\circ} \mathrm{C}$, J. Mater. Energy Syst., 1981, 3, p 39-47

14. B.M. Moshtaghioun and A. Monshi, Hot Corrosion Mechanism of Tundish Plaster with Steel Slags in Continuous Casting, J. Mater. Sci., 2007, 42, p 6720-6728

15. B.M. Moshtaghioun and A. Monshi, Analyze Complex Phases of SlagTundish Plaster Reactions by Modified XRD Ratio of Slopes Method for Some Kinetic Considerations, J. Mater. Process. Technol., 2008, 196, p 52-63

16. E.M. Levine, H.F. Mc Murdie, and F.P. Hall, Phase Diagram for Ceramists, The American Ceramic Society, Inc, Columbus, OH, 1956 